\title{
Penerapan Model Pembelajaran Kooperatif Tipe Student Teams Achievement Division untuk Meningkatkan Kemampuan Koneksi Matematis Siswa Kelas VII SMP Negeri 20 Pekanbaru
}

\author{
Hutri Defniati ${ }^{*}$ Zetriuslita ${ }^{* *}$, Mefa Indriati*
}

*,** Program Studi Pendidikan Matematika FKIP Universitas Islam Riau, Pekanbaru hutridepniati@yahoo.com, zetri.lita@gmail.com, indahwidiati@yahoo.com

\section{INFO ARTIKEL}

Riwayat Artikel:

Diterima: 12 Oktober 2018

Disetujui: 25 Juni 2019

\section{Kata kunci:}

Model Pembelajaran Kooperatif Student Teams Achievement Division Kemampuan Koneksi Matematis

\section{Alamat Korespondensi:}

Hutri Defniati,

Program Studi Pendidikan Matematika FKIP Universitas Islam Riau, Pekanbaru Email: hutridepniati@yahoo.com

\begin{abstract}
The purpose of this study is to improve the learning process and improve the ability of mathematical connections through the application of the Cooperative Learning model Student Teams Achievement Division, the form of this research is Classroom Action Research. The subjects in this study were students of class VII1 SMP Negeri 20 Pekanbaru with heterogeneous academic abilities. The study was conducted in the even semester of the academic year 2013/2014 consisting of two cycles. Data collection techniques used in this study were tests of mathematical connection ability at the end of the cycle, and observation sheets of teacher and student activities. The results of this study indicate that there is an improvement in the learning process from cycle I to cycle II and an increase in mathematical connection abilities. Increased mathematical connection ability can be seen from the scores on the mathematical connection ability test I (TKKM I) there is an increase from the basic score. The percentage on the base score is $36.42 \%$ while the percentage on the TKKM I score is $61.25 \%$. Increased mathematical connection ability can also be seen from an increase in TK2M II score of $90.25 \%$. From the results of the above research it can be concluded that the application of the Cooperative learning model of Student Teams Achievement Division can improve the learning process and improve students' mathematical connection skills in mathematics in class VII1 of SMP Negeri 20 Pekanbaru in the academic year 2013/2014 especially in the material of triangles and quadrilateral.
\end{abstract}

\begin{abstract}
Abstrak: Tujuan penelitian ini adalah untuk memperbaiki proses pembelajaran dan meningkatkan kemampuan koneksi matematis melalui penerapan model pembelajaran Kooperatif Tipe Student Teams Achievement Division, bentuk penelitian ini adalah Penelitian Tindakan Kelas. Subjek dalam penelitian ini adalah siswa-siswi kelas VII ${ }_{1} \mathrm{SMP}$ Negeri 20 Pekanbaru dengan kemampuan akademik yang heterogen. Penelitian dilaksanakan pada semester genap tahun ajaran 2013/2014 yang terdiri dari dua siklus. Teknik pengumpulan data yang digunakan pada penelitian ini adalah tes kemampuan koneksi matematis pada akhir siklus, dan lembar pengamatan aktivitas guru dan siswa. Hasi penelitian ini menunjukkan bahwa adanya perbaikan proses pembelajaran dari siklus I ke siklus II dan peningkatan kemampuan koneksi matematis. Peningkatan kemampuan koneksi matematis dapat dilihat dari skor pada tes kemampuan koneksi matematis I (TKKM I) ada peningkatan dari skor dasar. Persentase pada skor dasar yaitu 36,42\% sedangkan persentase pada skor TKKM I yaitu 61,25\%. Peningkatan kemampuan koneksi matematis juga dapat dilihat dari peningkatan pada skor TK2M II yaitu 90,25\%. Dari hasil penelitian di atas dapat disimpulkan bahwa penerapan model pembelajaran Kooperatif Tipe Student Teams Achievement Division dapat memperbaiki proses pembelajaran dan meningkatkan kemampuan koneksi matematis siswa pada mata pelajaran matematika kelas $\mathrm{VII}_{1} \mathrm{SMP}$ Negeri 20 Pekanbaru tahun ajaran 2013/2014 khususnya pada materi segitiga dan segiempat.
\end{abstract}




\section{LATAR BELAKANG}

Matematika mempunyai karakteristik khusus sehingga pembelajaran matematika perlu ditangani secara khusus pula. Satu karakteristik khusus matematika diantaranya adalah karakteristik yang menekankan pada proses deduktif yang memerlukan penalaran logis dan aksiomatik dan mungkin diawali dengan proses induktif. Selain dari pada itu, matematika juga dikenal sebagai ilmu yang terstruktur dalam arti antara bagian yang satu dengan bagian lainnya terjalin dalam hubungan yang erat. Oleh karena itu, penguasaan terhadap konsep dan prinsip matematika dapat dicapai bila disajikan dalam bentuk yang terkait antara satu dengan lainnya (Sumarmo, 2013). Tujuan belajar matematika dalam kehidupan kita sangatlah penting ini dikarenakan matematika merupakan pelajaran yang paling banyak digunakan di kehidupan manusia. Adapun menurut peraturan menteri no. 22 tahun 2006 (dalam BNSP, 2006) dinyatakan bahwa:

"Tujuan pendidikan nasional bidang pembelajaran matematika yaitu agar peserta didik memiliki kemampuan sebagai berikut: (1) Memahami konsep matematika, menjelaskan keterkaitan antar konsep dan mengaplikasikan konsep atau algoritma secara luwes, akurat, efisien, dan tepat dalam pemecahan masalah. (2) Menggunakan penalaran pada pola dan sifat, melakukan manipulasi matematika dalam membuat generalisasi, menyusun bukti atau menjelaskan gagasan dan pernyataan matematika. (3) Memecahkan masalah yang meliputi kemampuan memahami masalah, merancang model matematika, menyelesaikan model dan menafsirkan solusi yang diperoleh. (4) Mengkomunikasikan gagasan dengan simbol, tabel atau media lain untuk memperjelas keadaan atau masalah. (5) Memiliki sikap menghargai kegunaan matematika dalam kehidupan, yaitu memiliki rasa ingin tahu, perhatian dan minat dalam mempelajari matematika, serta sikap ulet dan percaya diri dalam pemecahan masalah".

Dari tujuan pendidikan nasional bidang pembelajaran matematika di atas maka dapat disimpulkan bahwa salah satu kemampuan yang harus dimiliki oleh siswa setelah belajar matematika adalah memahami konsep matematika, menjelaskan keterkaitan antar konsep dan mengaplikasikan konsep atau algoritma secara luwes, akurat, efisien, dan tepat dalam pemecahan masalah.. Fakta di lapangan berdasarkan observasi dan wawancara menunjukkan bahwa masih terdapat kondisi pembelajaran matematika yang kurang memfasilitasi siswa belajar matematika secara aktif, antara lain: (1) saat menjelaskan materi guru tidak menjelaskan keterkaitan antar konsep dan mengaplikasikan konsep. (2) proses pembelajaran masih berpusat pada guru. (3) hanya sebagian siswa saja yang fokus memperhatikan guru saat menjelaskan pelajaran. (4) guru memberikan tugas untuk siswa di LKS yang diterbitkan oleh penerbit. (5) guru tidak pernah menerapkan model pembelajaran kooperatif. (6) siswa merasa tidak terlibat dalam proses pembelajaran. Permasalahan-permasalahan tersebut dapat berakibat pada rendahnya kemampuan koneksi matematis dan berdampak pada rendahnya hasil belajar siswa. Hal ini bisa juga dilihat dari tabel rekapitulasi skor tes awal kemampuan koneksi matematis siswa kelas VII1 SMP Negeri 20 Pekanbaru. Skor yang diperoleh siswa dianalisis dan dikualifikasikan berdasarkan tingkat kemampuan koneksi matematis. Cara mengkualifikasi yang digunakan dimodifikasi dari Riduan dan Akdon (2007).

Secara keseluruhan total skor yang diperoleh siswa adalah 436 dari 1200 skor maksimal yang dapat diperoleh siswa. Berdasarkan hal tersebut maka tingkat kemampuan koneksi matematis siswa sangat rendah yaitu 36,3\%. Berdasarkan uraian pada tabel I.1 dan rata-rata tingkat kemampuan koneksi matematis, terlihat jelas bahwa kemampuan koneksi matematis siswa kelas VII1 SMPN 20 Pekanbaru masih rendah, untuk itu penulis memandang perlunya suatu model pembelajaran yang dapat memberikan kontribusi dalam upaya perbaikan proses pembelajaran matematika dan meningkatkan kemampuan koneksi matematika siswa. Peningkatan koneksi matematis tersebut dapat dilakukan dengan melakukan perubahan-perubahan dalam proses pembelajaran. Dalam hal ini perlu dirancang suatu pembelajaran yang memungkinkan siswa untuk terlibat secara langsung dalam proses pembelajaran. Salah satu cara yang dapat dilakukan untuk meningkatkan koneksi matematis adalah dengan melaksanakan model pembelajaran kooperatif tipe STAD.

Model pembelajaran kooperatif tipe STAD adalah salah satu model pembelajaran yang mengaktifkan siswa. Menurut Slavin (2009) menyatakan bahwa: "Setiap satu tim harus terdiri dari empat anggota jika memungkinkan. Tetapi jika pembagian tersebut tidak genap, siswanya bisa berjumlah lima orang atau ganjil. Pembelajaran Koopertif Tipe STAD adalah metode pembelajaran kooperatif untuk pengelompokan kemampuan campur yang melibatkan pengakuan tim dan tanggung jawab kelompok untuk pembelajaran individu anggota". Pembelajaran kooperatif tipe STAD telah digunakan dalam berbagai mata pelajaran seperti matematika, bahasa, seni, ilmu sosial dan ilmu pengetahuan alam. Model pembelajaran ini termasuk model pembelajaran yang cukup sederhana. Menurut Trianto (2009) fase-fase pembelajaran kooperatif tipe STAD adalah: 1) Fase 1 menyampaikan tujuan dan memotivasi siswa; 2) Fase 2 menyajikan atau menyampaikan informasi; 3) Fase 3 mengorganisasi siswa ke dalam kelompok-kelompok belajar; 4) Fase 4 membimbing kelompok bekerja dan belajar; 5) Fase 5 evaluasi; 6) Fase 6 memberikan penghargaan.

Untuk mengetahui perkembangan kelompok maka skor kelompok ini dihitung dengan membuat rata-rata skor perkembangan anggota kelompok, yaitu dengan menjumlahkan semua skor perkembangan yang diperoleh anggota kelompok dibagi dengan jumlah anggota kelompok. Perlu diingat bahwa skor tim lebih tergantug pada skor kemajuan daripada skor awal. Penelitian ini bertujuan untuk memperbaiki proses pembelajaran dan meningkatkan 
kemampuan koneksi matematis siswa kelas VII1 SMP Negeri 20 Pekanbaru Tahun Ajaran 2013/2014 Semester Genap melalui penerapan model pembalajaran kooperatif tipe STAD pada materi Segitiga dan Segi Empat.

\section{METODE}

Bentuk penelitian ini adalah penelitian tindakan kelas (PTK). Penelitian tindakan kelas merupakan salah satu kegiatan untuk mengatasi masalah yang terdapat di dalam kelas. Penelitian tindakan kelas (PTK) adalah suatu kegiatan penelitian ilmiah yang dilakukan secara rasional dan sistematis terhadap berbagai tindakan yang dilakukan oleh guru (tenaga pendidik), kolaborasi (tim peneliti), sejak disusunnya suatu perencanaan sampai penilaian terhadap tindakan nyata didalam kelas yang berupa kegiatan belajar mengajar, untuk memperbaiki dan meningkatkan kondisi pembelajaran yang dilakukan (Iskandar, 2009). Dalam penelitian ini, guru bertindak sebagai pelaksana tindakan pada kelas yang dijadikan sebagai subjek dan peneliti sebagai pengamat selama proses pembelajaran dengan menggunakan model pembelajaran kooperatif tipe Student Teams Achievement Division (STAD). Dengan demikian, penelitian ini termasuk jenis penelitian tindakan kelas kolaboratif. Tindakan yang akan dilakukan adalah pembelajaran dengan model pembelajaran koooperatif tipe Student Teams Achievement Division (STAD) dalam hal meningkatkan kemampuan koneksi matematis siswa kelas VII1 SMP Negeri 20 Pekanbaru. Karena jenis penelitian ini adalah penelitian tindakan kelas, maka berdasarkan karakteristik penelitian ini terdapat suatu siklus perbaikan terhadap proses pembelajaran. Dalam penelitian ini dilakukan dua siklus. Siklus pertama terdiri dari 3 kali pertemuan ditambah 1 kali tes kemampuan koneksi matematis, siklus kedua terdiri dari 4 kali pertemuan ditambah 1 kali tes kemampuan koneksi matematis. Pada siklus pertama dilakukan tindakan sesuai dengan model pembelajaran kooperatif tipe STAD. Selanjutnya, siklus kedua merupakan tindakan yang akan dilakukan berdasarkan hasil refleksi dari sikus pertama. Instrumen penelitian terdiri dari perangkat pembelajaran berupa silabus, Rencana Pelaksanaan Pembelajaran (RPP), dan Lembar Kerja Siswa (LKS), serta instrumen pengumpulan data yang terdiri dari tes kemampuan koneksi matematis, lembar pengamatan aktivitas guru dan siswa dan kuis pada setiap pertemuan. Teknik pengumpulan data pada penelitian ini adalah teknik tes dan teknik pengamatan. Analisis data tentang aktivitas guru dan siswa dianalisis secara kualitatif. Sedangkan kemampuan koneksi matematis dianalisis dengan menghitung skor dan persentase setiap indikator.

\section{HASIL DAN PEMBAHASAN}

Dari pelaksanaan tindakan diperoleh bahwa pada siklus I dan siklus II sudah terjadi perbaikan pada proses pembelajaran. Jika dibandingkan dengan sebelum tindakan yang mana pada kegiatan awal guru tidak menyampaikan tu-juan pembelajaran, dan memotivasi siswa. Guru juga tidak mengaitkan materi dengan kehidupan sehari-hari. Pada kegiatan inti guru menyampaikan dan menjelaskan materi kepada siswa secara keseluruhan. Setelah menjelaskan, guru menanyakan materi mana yang belum dipahami oleh siswa. Kemudian guru memberikan soal latihan kepada siswa di LKS yang diterbitkan penerbit. Pada kegiatan akhir guru tidak memberikan soal evaluasi sehingga guru tidak dapat mengetahui apakah siswa telah paham dengan apa yang diajarkan.

Kemudian pada siklus I yang mana pada kegiatan awalnya aktivitas yang dilakukan oleh guru dan siswa belum terlaksana dengan baik, masih ada langkah-langkah pembelajaran yang belum dilaksanakan oleh guru. Seperti guru masih lupa menyampaikan tujuan pembelajaran, memotivasi siswa. Guru juga belum optimal melakukan koneksi pembelajaran. Pada saat pembentukan kelompok masih ada siswa yang ribut dan menolak untuk duduk berkelompok. Pada kegiatan intinya saat siswa mengerjakan LKS secara individu masih ada sebagian siswa yang tidak mengerjakan secara individu, tetapi mencatat LKS teman sekelompok sampai habis. Siswa juga masih malu-malu pada saat mempresentasikan hasil diskusinya. Pada kegiatan akhirnya hasil kuis siswa juga kurang maksimal. Pada saat menyimpulkan pelajaran siswa kurang berperan aktif sehingga hanya guru yang menyimpulkan pelajaran.

Selanjutnya, pada siklus II yang mana pada kegiatan awalnya aktivitas yang dilakukan oleh guru dan siswa sudah terlaksana dengan baik, guru telah menyampaikan tujuan pembelajaran dan telah menyampaikan motivasi pada siswa. Guru telah melakukan koneksi pembelajaran dengan baik dan optimal. Pada saat pembentukan kelompok siswa tertib dan tidak ribut lagi karena telah terbiasa. Siswa juga lebih senang dengan kelompok kooperatif yang kedua. Pada kegiatan intinya saat siswa mengerjakan LKS secara individu sswa telah mengerjakan secara individu sesuai dengan waktu yang diberikan. Saat presentasi siswa tidak malu-malu lagi dan sudah banyak siswa yang berani bertanya jika tidak mengerti. Saat kegiatan akhirnya Hasil kuis siswa juga sudah meningkat dan pada saat menyimpulkan pelajaran siswa sudah berperan aktif. Berdasarkan uraian di atas dapat diketahui bahwa aktivitas guru dan siswa pada model pembelajaran kooperatif tipe STAD pada siklus kedua mengalami peningkatan dari pada siklus pertama, dimana pada siklus kedua aktivitas guru dan siswa telah dilaksanakan dengan sangat baik sesuai dengan acuan rancana pelaksanaan pembelajaran (RPP) yang telah dirancang sehingga terjadi proses perbaikan proses pembelajaran dan peningkatan kemampuan koneksi matematis siswa.

Setelah dilakukan analisis data tentang penerapan model pembelajaran tipe STAD pada materi segitiga dan segiempat. Dari hasil analisis data menunjukkan bahwa adanya peningkatan kemampuan koneksi matematis siswa 
kelas VII $_{1}$ SMP Negeri 20 Pekanbaru setelah dilaksanakan penelitian tindakan kelas melalui model pembelajaran kooperatif tipe STAD.

Tabel 1. Analisis Rata-rata Kemampuan Koneksi Matematis

\begin{tabular}{lccc}
\hline & TES awal & TKKM I & TKKM II \\
\hline Jumlah siswa & 40 & 40 & 40 \\
Skor Ideal & 1200 & 1200 & 1200 \\
Jumlah Skor siswa & 436 & 735 & 1083 \\
Jumlah Persentase Keseluruhan & $36,33 \%$ & $61,25 \%$ & $90,25 \%$ \\
\hline Rata-rata Kemampuan Koneksi Matematis & 36,33 & 61,23 & 90,25 \\
\hline
\end{tabular}

Dari tabel 1 telihat bahwa persentase kemapuan koneksi matematis mengalami peningkatan dari skor dasar, TKKM I dan TKKM II. Persentase kemampuan koneksi matematis pada skor dasar yaitu 36,33\%, TKKM I yaitu 61,25\% danTKKM II sebesar 90,25\%. Kemudian rata-rata pada skor dasar 36,33, pada TKKM I adalah 61,23 dan pada TKKM II adalah 90,25. Berdasarkan uraian di atas dapat disimpulkan bahwa kemampuan koneksi matematis dapat ditingkatkan melalui penerapan model pembelajaran kooperatif tipe STAD. Jadi hasil analisis tindakan ini mendukung hipotesis tindakan yang diajukan.

\section{SIMPULAN DAN SARAN}

\section{Simpulan}

Berdasarkan hasil penelitian pada siklus I dan siklus II, maka dapat diambil kesimpulan bahwa penerapan model pembelajaran kooperatif tipe Student teams Achievement Division (STAD) dapat memperbaiki proses pembelajaran dan meningkatkan kemampuan koneksi matematis siswa kelas VII ${ }_{1}$ SMP Negeri 20 Pekanbaru tahun ajaran 2013/2014 semester genap pada materi segitiga dan segiempat.

\section{Saran}

Saran yang disampaikan adalah dengan adanya peningkatan yang signifikan tersebut, sekolah lebih memperhatikan kemampuan koneksi matematis dengan memberikan fasilitas dan prioritas terhadap hal yang dapat memacu kemampuan siswa sehingga cita-cita siswa dapat tercapai dengan lebih baik sesuai harapan yang ada. Secara umum penilaian STAD hendaknya didasarkan pada sebuah tujuan yang jelas, memiliki dukungan kemampuan koneksi matematis agar jelas dalam mengadaptasi perubahan kurikulum pendidikan di sekolah.

\section{DAFTAR RUJUKAN}

Badan Standar Nasional Pendidikan. 2006. Standar dan Kompetensi Dasar. Jakarta: Depdiknas.

Iskandar. 2009. Penelitian Tindakan Kelas. Bandung: Gaung Persada.

Slavin, R. E. 2009. Cooperative Learning: Teori, Research dan Praktik. Bandung: Nusa Media.

Sudjana,Nana. 2009. Penilaian Hasil Belajar Proses Belajar Mengajar. Bandung: PT Remaja Rosdakarya Offset.

Sumarmo, Utari. 2013. Kumpulan Makalah Berpiir dan Disposisi Matematik Serta Pembelajarannya. Bandung: Universitas Pendidkan Indonesia.

Trianto. 2009. Mendesain Model Pembelajaran Inovatif Progresif. Surabaya: Prenada Media. 